\title{
Obituary
}

\section{Prof. Udai Shankar Mishra}

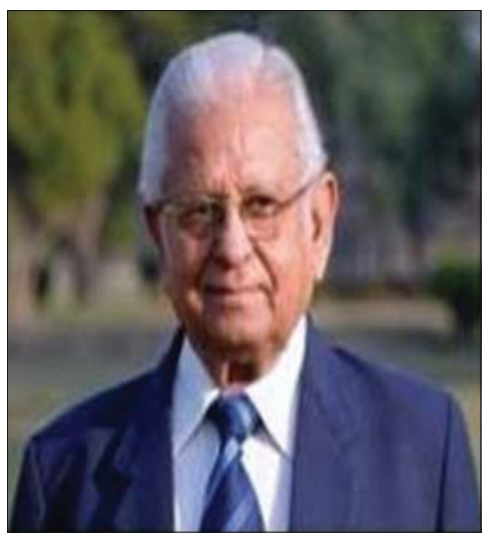

Prof. Udai Shankar Mishra

(17 Jan 1936 - 06 Jun 2013)

Prof. Udai Shankar Mishra did MBBS from Prince of Wales Medical College, Patna. Prof. US Mishra started his illustrious career as a Medical Officer in Leh. Subseqently, after spending 3 years in Leh, he joined as a Registrar in Banaras Hindu University. His quest for excellence took him to UK where he earned his degrees of FRCS and Mch in Orthopaedics. After spending five years in UK, his interest to serve his own country brought him back to India and joined as a faculty in Moti Lal Nehru Medical College, Allahabad. He continued his journey ahead and became the Head, department of orthopaedics in Baba Raghav Das Medical College, Gorakhpur. His excellence in academics gave him the most sought after chair of Head, department of orthopaedics at King George Medical College, Lucknow in 1986.

He had an additional charge of Director-Professor of Department of Physical Medicine and Rehabilitation and Honorary consultant to Northern Railways. He retired in the year 1996 and his Guru Mantra was "Do not run after money, money will run after you".
Prof. Mishra had more than 30 publications and has contributed too many books, including Campbell's Operative Orthopedics. He delivered prestigious Prof. B. N. Sinha Oration and Dr. Anil Gupta Memorial Lectures.

During his 38 years of teaching tenure, he was examiner to most universities of this country for MS, DNB and $\mathrm{PhD}$ in Orthopedics. He was technical expert in Public Services Commission, AIIMS, AMU and many more.

He was member executive committee of IOA, President Uttar Pradesh Orthopedic Association, fellow of British Orthopedic Association and founder member of AFICOT and ASAMI. Prof. Mishra was awarded Hon. Fellowship of IOA in 2007. He was given life time achievement award of UP Orthopedic Association.

Prof. Mishra was a cool person, a great teacher, a perfect surgeon and a kind hearted man with pleasant and smiling personality. He passed away peacefully on June 6, 2013.

\section{Harish Kohli}

Consultant Orthopaedic Surgeon, Hari Ram Kohli Memorial Nursing Home and Clinic, 2, Haridwar Road, Dehradun - 248 001, Uttrakhand, India E-mail:drharishkohli@gmail.com

\begin{tabular}{|c|c|}
\hline \multicolumn{2}{|c|}{ Access this article online } \\
\hline Quick Response Code: & \\
\hline & Website: \\
\hline & www.joonline.com \\
\hline
\end{tabular}

